Article

\title{
Substrate Composition and Depth Affect Soil Moisture Behavior and Plant-Soil Relationship on Mediterranean Extensive Green Roofs
}

\author{
Julie Chenot ${ }^{1,2,3, *}$ (D), Elie Gaget ${ }^{4,5}$ (D), Cannelle Moinardeau ${ }^{2}$, Renaud Jaunatre ${ }^{3}$, \\ Elise Buisson ${ }^{2}$ and Thierry Dutoit ${ }^{2}$ \\ 1 Société des Carrières de La Ménudelle, 13. BP 80011, 13551 Saint-Martin-de-Crau, France \\ 2 Institut Méditerranéen de Biodiversité et d'Ecologie (IMBE), Université d'Avignon et des Pays de Vaucluse, \\ UMR CNRS IRD Aix Marseille Université, IUT site Agroparc, BP 61207, 84911 Avignon CEDEX 09, France; \\ cannelle.moinardeau@univ-avignon.fr (C.M.); elise.buisson@univ-avignon.fr (E.B.); \\ thierry.dutoit@univ-avignon.fr (T.D.) \\ 3 Irstea Grenoble, UR Écosystèmes Montagnards, University Grenoble Alpes, Irstea, UR EMGR, \\ 2 rue de la Papeterie, BP 76, 38402 Saint-Martin-d'Hères, France; renaud.jaunatre@irstea.fr \\ 4 Institut de Recherche Pour la Conservation des Zones Humides Méditerranéennes, Tour du Valat, \\ Le Sambuc, 13200 Arles, France; gaget@tourduvalat.org \\ 5 Muséum National d'Histoire Naturelle, Conservation des Espèces, Restauration et suivi des \\ Population-UMR 7204 MNHN-CNRS-UPMC, 55 rue Buffon, 75005 Paris, France \\ * Correspondence: chenot.julie@gmail.com
}

Received: 31 August 2017; Accepted: 19 October 2017; Published: 25 October 2017

\begin{abstract}
The Mediterranean basin is extremely vulnerable to climate change, and one of the areas most impacted by human water demand. Yet the green roofs increasingly created both for aesthetic reasons and to limit pollution and urban runoff are themselves very water-demanding. Successful green roof installation depends on the establishment of the vegetation, and the substrate is the key element: it conserves water, and provides the nutrients and physical support indispensable for plant growth. Since typical Mediterranean plant communities require no maintenance, this study seeks to develop techniques for creating maintenance- and watering-free horizontal green roofs for public or private buildings in a Mediterranean context. The innovative aspect of this study lies in creating two soil mixes, fine elements (clay and silt) and coarse elements (pebbles of all sizes), in two different thicknesses, to assess vegetation development. Monitoring of substrate moisture was carried out and coupled with local rainfall measurements during summer and autumn. As expected, substrate moisture is mainly influenced by substrate depth (the deeper, the moister) and composition (the finer the particles (clays and silts), the higher the moisture content). Vegetation cover impacts moisture to a lesser extent but is itself affected by the composition and depth of the substrates. These results are subsequently discussed with relation to the issue of sustainable green roofs in Mediterranean climates. Considering applications of our results, for an optimal colonization of a Mediterranean vegetation, a substrate thickness of $15 \mathrm{~cm}$ composed mainly of fine elements ( $75 \%$ clay-silt and $25 \%$ pebble-sand) would be recommended in green roofs.
\end{abstract}

Keywords: extensive green roofs; soil moisture; substrate depth; substrate composition; Mediterranean context

\section{Introduction}

Green roofs are new urban ecosystems currently attracting strong interest from both scientists and the general public [1]. They are internationally recognized for the wide range of ecosystem services they offer in urban settings [2,3]. In particular, green roofs are known to provide aesthetic and psychological 
benefits and to mitigate extreme urban temperatures [4-6]. In addition, they can partially offset the loss of green areas by replacing impermeable surfaces. Green roofs help increase urban biodiversity by providing habitats and food resources for many species $[7,8]$, including many indigenous species of flora and fauna $[9,10]$. Other benefits include city noise reduction, thermal insulation, increased roof membrane durability, improved air quality due to their filtering of many air pollutants, improved rainwater sanitation and retention of storm runoff $[5,11,12]$. As a result, green roofs are becoming increasingly common in a large part of the world [2]. However, know-how in terms of green roof installation is, in some cases, inadequate to deal with the contrasting environmental conditions that prevail in the Mediterranean region. Research on green roofs currently focuses on cold climates, and may not take into account prolonged periods of drought, extreme temperatures or heavy precipitation, the future climatic conditions due to global changes [3,13-15]. In the Mediterranean context, such severe conditions impose severe restrictions on plant growth and on plant survival [16]. Water is one of the most common limiting factors for the development of plants [17-19]. It has already been demonstrated that plants cannot survive on non-irrigated green roofs when the substrate depths are less than $5 \mathrm{~cm}$, and this risk increases during summer drought or during plant establishment [20]. Unfortunately, summer water shortages, a recurring problem in the Mediterranean region, are expected to increase according to climate change scenario forecasts [21]. Yet green roof irrigation is an unsatisfactory long-term option, both economically and ecologically. Thus, it is important to ensure that both vegetation and substrate are able to withstand the absence of irrigation. Knowledge of plant requirements and performance in their natural environment will identify those species most suited to local climatic conditions and therefore potentially usable on green roofs [22]. However, this hypothesis is valid only if environmental conditions for the green roofs are not too different from those of the plants' natural environment.

It is thus recognized that the establishment of vegetation cover is a limiting step in the installation of green roofs [23]. This step depends strongly on the substrate, without which the vegetation can only rarely settle. The substrate is therefore probably the most important element of a green roof, allowing water and nutrients to be preserved and thereby providing the physical support essential to the plants [19]. Extensive green roofs ( $\leq 150 \mathrm{~mm}$ deep) must meet the physical, chemical and biological needs of plants via a substrate ideally combining the following properties: nutrient inputs; efficient water absorption and retention; good drainage; effective plant anchoring, and; lightweight enough for the roof to carry [24,25]. This ideal substrate can be obtained in various ways. European and international recommendations for green roof supports involve substrates based on granular mineral materials or lightweight aggregates, such as volcanic pumice (pozzolana), expanded slate, sand, crushed brick or concrete $[26,27]$. In other cases, composted materials are commonly used as substrate $[28,29]$. The ideal substrate results in a freely draining combination of coarse aggregates, with more or less organic content [30]. For increased durability, recycled materials or quarry by-products should be used to limit financial and ecological costs and promote sustainable development. This study is original in considering the installation of extensive green roofs using unrefined materials (thus not extensively treated coarse elements and sand) and recycled materials originally intended for disposal, such as sludge from quarrying (composed exclusively of clays and silts).

The selection of plant species for green roofs is complicated by the harsh urban environments and the often extreme temperatures and drought the plants are subjected to, aggravated by their thin substrate and elevated position [31]. It is therefore important to establish plant selection criteria prior to implementation [22]. In the case of Mediterranean green roofs, the main criteria are drought tolerance, their indigenous nature, aesthetic characteristics (to ensure acceptance by the general public) and low maintenance requirements [3,16,23,32]. Regional plant communities can thus serve as a model for the recruitment and installation of seeds on green roofs [22,32,33], being composed of stress-adapted species and ruderal species that have the capacity to maximize resources. Moreover, ecological theory suggests that diverse vegetation is more resistant and resilient 
to severe environmental stress. Strong plant and functional diversity also make green roofs more aesthetically pleasing even under dry conditions [34,35]. This is why typical vegetation communities in the Mediterranean region were sampled for this study.

Here, we sought to develop substrates for the creation of horizontal green roofs on public or private buildings in the Mediterranean region, partly using recycled quarry waste without any future maintenance after their installation. In this innovative approach, fine elements (clays and silts) were mixed with coarse elements (pebbles of all sizes) with the aim of allowing typical pioneer Mediterranean vegetation communities to be maintained without human intervention (no watering, mechanical or chemical weeding). We assessed the role of substrate thickness and composition in maintaining the moisture necessary for good vegetation cover. Substrates of various compositions were tested using different thicknesses, and their moisture was monitored against local rainfall readings during (summer) and after (autumn) the Mediterranean drought period.

Our hypotheses were (1) that thicker substrates $(15-\mathrm{cm})$ would better retain rainwater and thus exhibit greater moisture over a longer period than thin substrates $(5-\mathrm{cm}) ;(2)$ that substrates composed of coarser materials would retain less rainwater and therefore provide better drainage [36]; (3) that thin substrates would dry out more rapidly, thereby limiting vegetation cover.

\section{Materials and Methods}

\subsection{Study Site Location}

Our experimental site is located in Mediterranean Southeastern France, on the roofs of Avignon University and Technology Institute (lat: 43.909885 , long: 4.88857). The site is conducive to green roof installation, providing: (1) a flat roof (with a very slight slope allowing the evacuation of rainwater) and (2) high sun exposure.

\subsection{Climate and Soil Moisture}

According to a meteorological report covering 24 years (1989-2012), the study area is characterized by a typically Mediterranean climate, with hot and dry summers marked by prolonged droughts and mild winters punctuated by very cool periods with frost [37]. The average annual temperature is $14{ }^{\circ} \mathrm{C}$ with maximum temperatures in July $\left(24^{\circ} \mathrm{C}\right)$ and minimum in January $\left(6^{\circ} \mathrm{C}\right)$. The region is swept by the Mistral, a cold, dry and violent dominant wind (up to 50 days a year of Mistral storm, defined by a recorded speed of more than $57 \mathrm{~km} / \mathrm{h}$ (16 days a year with wind speed $>100 \mathrm{~km} / \mathrm{h}$ ) [38]. This wind is responsible for Avignon's clear skies and thus an average of $2600 \mathrm{~h}$ of sunshine per year, strongly accentuating the drought The rainfall regime, which is typically Mediterranean and marked by a very uneven distribution of rainfall during the year, is characterized by two rainy periods, in autumn ( $40 \%$ of annual rainfall between September and November) and spring ( $25 \%$ from March to May). The average annual precipitation does not exceed $700 \mathrm{~mm}$, characterized by a few heavy rainfalls (about 45 rainy days per year) $[39,40]$.

\subsection{Experimental Protocol}

The experiment involved extensive green roofs composed of four layers: (1) the roof of the building (concrete), capable of supporting the weight of the green roof and with a waterproof seal, on which we installed (2) a drainage system consisting of a layer of pebbles to prevent water stagnation and to facilitate its flow; (3) a geotextile filter retaining the substrate fine particles and allowing the water contained in the substrate to flow; and (4) the substrate essential to the proper development of the vegetation. Several substrates of varying depth and composition were tested. We applied two substrate thicknesses, of $5 \mathrm{~cm}$ and $15 \mathrm{~cm}$, falling within the classical range for extensive green roofs found in literature [20,32,41]. Two types of material were used: (1) fine elements from quarry sludge composed exclusively of clays and silts; (2) raw materials with a particle size range of 0-30 mm and originating from Durancian gravel (known by scientists as geological material 
and which quarries consider exploitable deposit, screened (sorted) with minimum storage to limit recruitment of seed from undesirable species (anemochorous Asteraceae in particular). These materials came from a dry alluvial quarry located in the Paleodelta of the Durance River, in the plain of La Crau (Bouches-du-Rhône, France) $60 \mathrm{~km}$ south of the experimental site. Because using inorganic substrate alone may limit plant growth, organic matter was added $[28,42,43]$. This organic amendment (NF U 44-051) was in the form of green compost with 52\% dry matter, $22 \%$ organic matter, $0.75 \%$ total nitrogen and potassium oxide for up to $0.5 \%$ of the mass of the crude product. Three mixtures composed of different proportions of the materials were tested (Table 1, Figure 1).

Table 1. Composition of the six substrates tested on the green roof.

\begin{tabular}{ccccc}
\hline Depth (cm) & Coarse Materials (\%) & $\begin{array}{l}\text { Fine Materials } \\
\text { (Clay-Silt) } \mathbf{( \% )}\end{array}$ & $\begin{array}{c}\text { Compost } \\
\text { (\% of Total Substrate Volume) }\end{array}$ & Number of Quadrats \\
\hline 5 & 75 & 25 & 3 & 16 \\
15 & 75 & 25 & 3 & 16 \\
5 & 50 & 50 & 3 & 16 \\
15 & 50 & 50 & 3 & 16 \\
5 & 25 & 75 & 3 & 16 \\
\hline
\end{tabular}
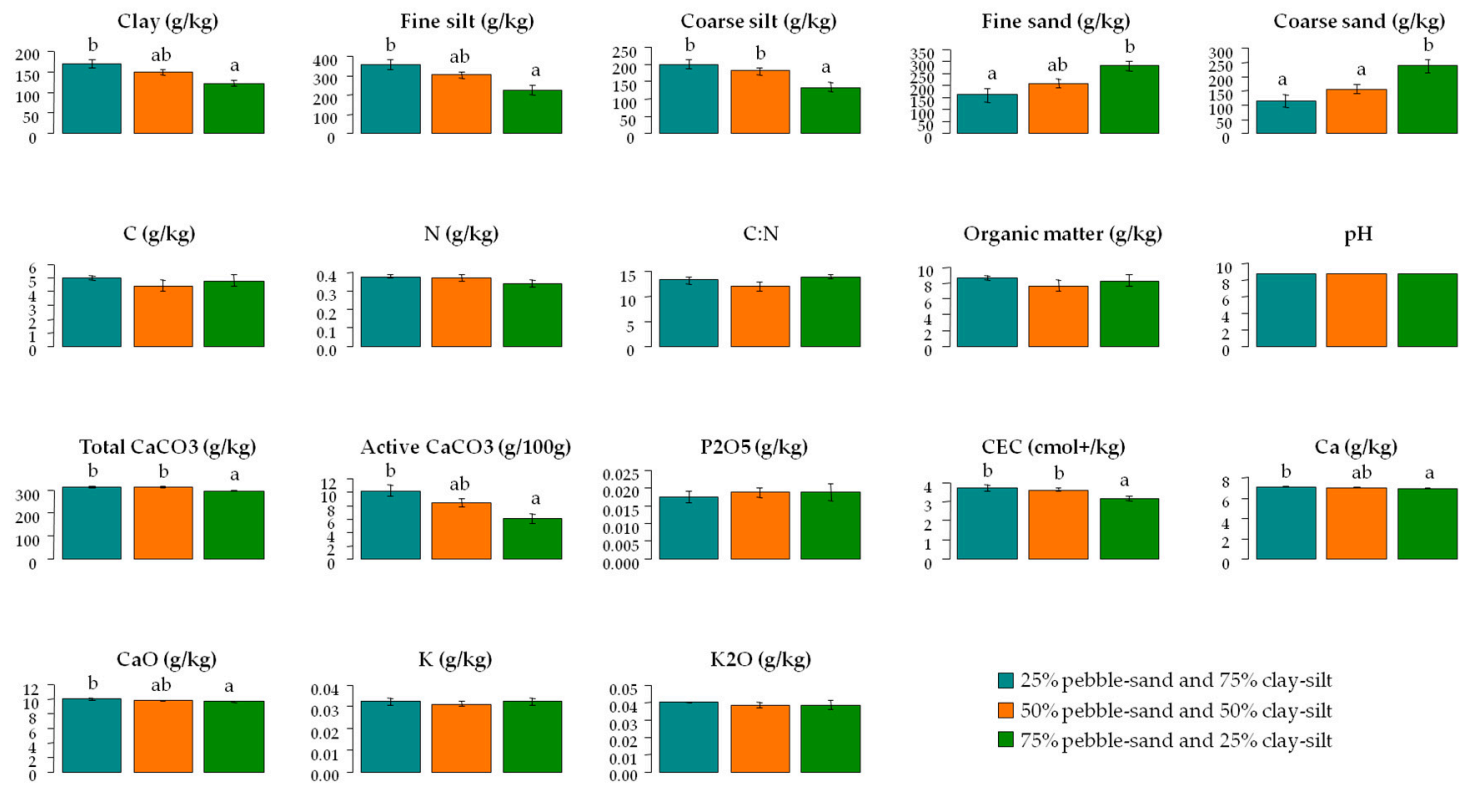

Figure 1. Physical and chemical analyses of the different substrates carried out in summer 2016 and performed by the soil analysis laboratory at INRA (Institut National de la Recherche Agronomique) in Arras by extraction ( $\mathrm{pH}$ water ratio 1:5) [44], $\mathrm{CaCO} 3$ using a Bernard calcimeter [45], organic C [46] and total $\mathrm{N}$ by dry combustion [47,48], C:N ratio, Cation Exchange Capacity (CEC) and exchangeable $\mathrm{K}+$ by Metson [49,50], plant available P [51] and the particle-size distribution in five fractions by the Robinson method without prior decarbonization (clay $(<0.002 \mathrm{~mm})$, fine silt $(0.002-0.02 \mathrm{~mm})$, coarse silt $(0.2-2 \mathrm{~mm})$, fine sand $(0.05-0.2 \mathrm{~mm})$ and coarse sand $(0.2-2 \mathrm{~mm})$ ). The given values are means \pm standard errors. Two values in the same row with a different letter are significantly different according to Tukey post hoc tests or Mann-Whitney-Wilcoxon tests (with Bonferroni adjustment [52]).

The mixtures were obtained and plated in the form of quadrats of $1 \mathrm{~m}^{2}$ using hand tools. The materials were mixed with a cement mixer, stirred and therefore ventilated to ensure better plant growth [53]. A total of 96 quadrats separated from each other were installed on the roof in April $2016(\mathrm{~N}=96=16$ replicates $\times 3$ compositions $\times 2$ thicknesses) (Figure 2). After this installation, no maintenance was carried out (no watering or weeding). 


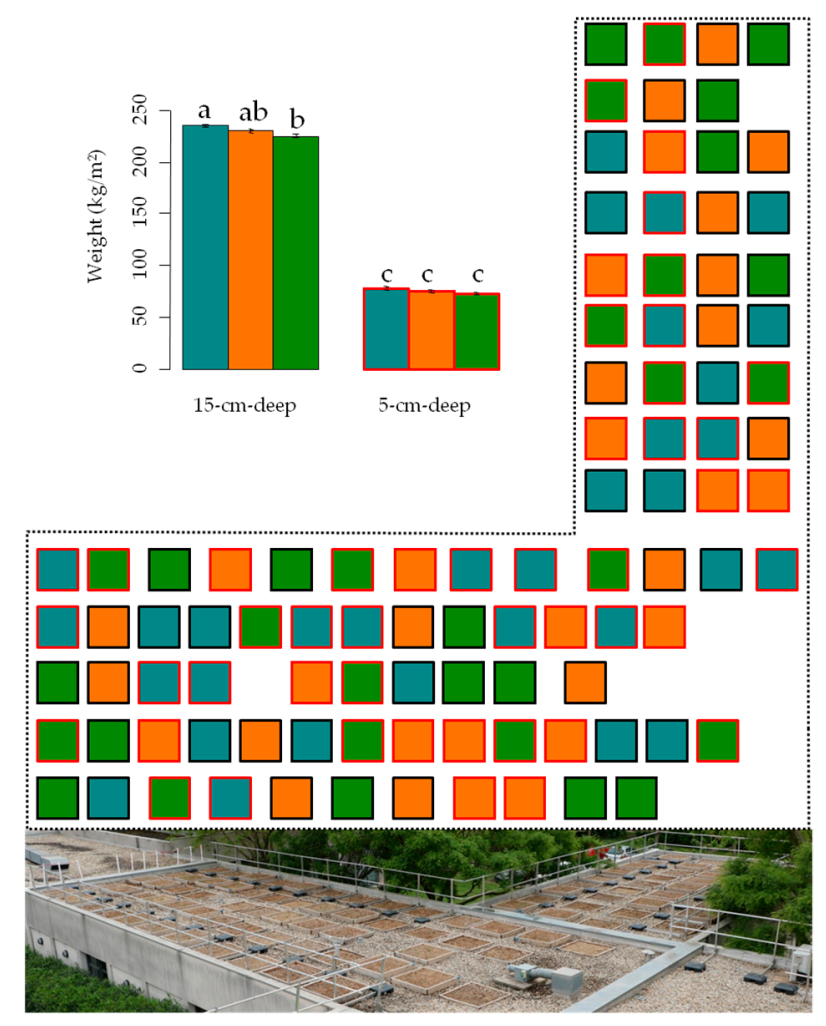

Figure 2. Experimental design and weight of the 96 quadrats installed on the roof of Avignon Technology Institute (IUT) (Southeastern France). Mixtures are indicated by the color background (blue: $25 \%$ pebble-sand and $75 \%$ clay-silt; orange: 50\% pebble-sand and $50 \%$ clay-silt; green: $75 \%$ pebble-sand and $25 \%$ clay-silt) and the substrate thicknesses by the color of the quadrats framing (red: $5 \mathrm{~cm}$, black: $15 \mathrm{~cm}$ ). The given values are means \pm standard errors. Two values in the same row with a different letter are significantly different according to Mann-Whitney-Wilcoxon test (with Bonferroni adjustment [52]).

The implanted plant communities (thereafter named inoculum) correspond to the Crassuletum tilliaeae phytosociological association of the plain of La Crau, dominated by cryptogams and annual plant species [53]. They develop on clay-limestone and thin soils where rainwater stagnates and are characterized by calcicolous and acidophilic species dominated by lichens and mosses. This association is recognizable from the abundance of a small red Crassulaceae, Crassula tillaea, and from its numerous annual species (Filago pygmaea, Logfia gallica, Reichardia picroides, etc.) $[53,54]$. This plant community is particularly interesting in terms of species richness, composition and diversity [55-57].

Plant communities were established by inoculum in April 2016. This inoculum correspond to the first two centimeters of soil were harvested from small areas on the ground (110 samples of $30 \mathrm{~cm} \times 30 \mathrm{~cm}$ in June 2015) and which were subsequently bulk transferred onto the quadrats on the experimental roof. The transient seed bank of these plant communities present in the inoculum could therefore be expected to yield a pool of species adapted to the Mediterranean environment and whose structure was based on natural species coexistence [53,58-60]. The vegetation percent cover was visually estimated in June and November 2016.

\subsection{Substrate Moisture Measurement and Rainfall Monitoring}

The evolution of substrate moisture in the 96 quadrats was studied every two days after rain, with a ThetaProbe type ML2X probe and an HH2 Moisture Meter (class leading $\pm 1 \%$ soil moisture accuracy). The ThetaProbe measures the volumetric moisture content of the substrate $(\theta \mathrm{v})$, responding to changes in the apparent dielectric constant of the wet substrate: from 0.05 to 
$0.6 \mathrm{~m}^{3} \cdot \mathrm{m}^{-3}$ of water content depending on the ThetaProbe used [61]. Thus, the moisture of the substrate under consideration is moisture volume expressed as a percentage (vol \%). For each quadrat, measurements were made three times and only their average was used for analyses.

The first moisture survey was carried out in summer 2016 from 17 June to 4 July, after a rainfall of $11 \mathrm{~mm}$ between 15 June and 16 June (summer survey evapotranspiration: ETosummer 2016 survey period $=77.28 \mathrm{~mm}$ so the average ETo rate for summer is $4.29 \mathrm{~mm} \cdot \mathrm{day}^{-1}$, Thornthwaite method [62]). A second survey was conducted in autumn 2016 from 7 to 18 November, between two rainfalls (following a precipitation of $43.5 \mathrm{~mm}$ over 4 and 5 November) (autumn survey evapotranspiration: ETo $_{\text {Autumn }} 2016$ survey period $=9.90 \mathrm{~mm}$ so the average ETo rate for autumn is 0.825 $\mathrm{mm} \cdot$ day $^{-1}$, Thornthwaite method). A meteorological station was installed on the experimental roof at the beginning of the experiment, to provide accurate, consistent and reliable data for monitoring. Precipitation heights and temperatures accurate to the nearest tenth of a millimeter were recorded every hour and averaged daily (Figure 3).
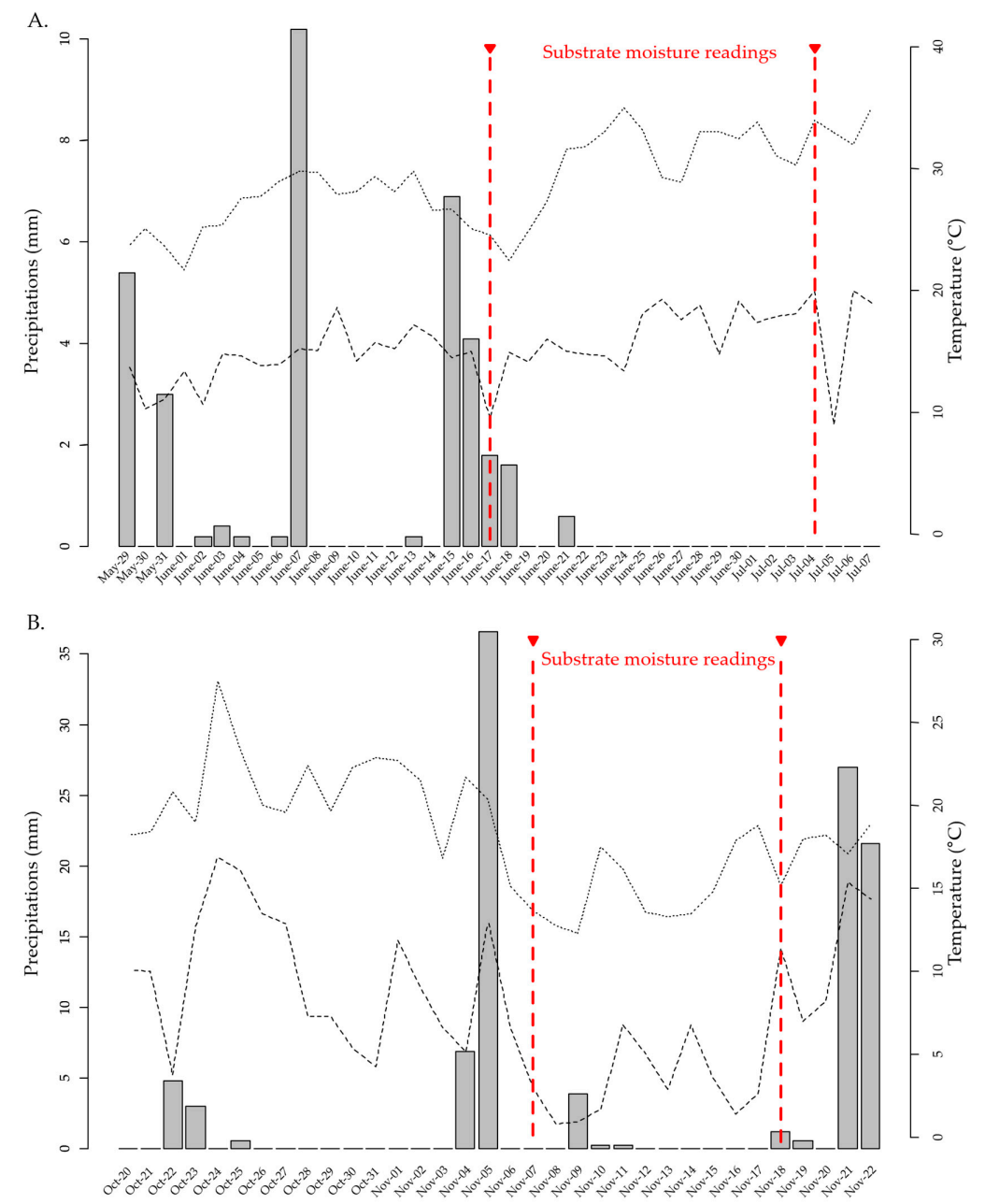

Figure 3. Periods of surveys in June (A) and November (B) 2016 as related to periods of precipitation preceding the experimentation on the roof of Avignon Technology Institute (IUT) (Southeastern France). Lines represent minimum and maximum temperatures and bars represent precipitation.

\subsection{Statistical Analysis}

First, we explored how soil moisture varies according to substrate thickness and substrate composition, considering the probable interaction between these two variables. Soil moisture variation was assessed under a statistical modeling approach taking into account the distribution of moisture 
data as a function of the seasons. In autumn, moisture followed a normal distribution, allowing the use of a Generalized Linear Model (GLM) in Gaussian distribution [63,64]. The model was validated by observing the distribution of residuals. In summer, since moisture followed a Poisson distribution, it was initially modeled using a GLM with a Poisson distribution. However, strong structuration of the residuals was detected on the day effect. For this reason, a Generalized Least Squares (GLS) model was run, with a logarithmic transformation of the humidity variable and with the model weighted to account for the survey day effect. This consists in attributing weights to variables to attenuate or increase their relative influence $[65,66]$. The model was validated by observing residual patterns under the effect of the weighting. Given the temporal dimension of the study, the effect of the continuous variable was added, as well as its interactions with substrate thickness and composition. The significance of the variables was obtained on ANOVA models. The importance of the plant cover effect in the model was initially compared with an AIC criterion (Akaike Information Criteria [67]): the model were not improved by the addition of the plant cover (delta AIC > 2 [66]), so it was discarded from the model. Second, we assessed plant cover evolution, modeling it with a GLM with binomial negative distribution to study the effect of substrate thickness and composition. In this model, the data for the two seasons were concatenated and a season effect was placed in fixed effects and in interaction with the two other explanatory variables.

All statistical analyses were carried out with statistical software R version 3.3.1 [68], and its "nlme" packages [69] and "lme4" packages [70].

\section{Results}

\subsection{Influence of the Different Variables Measured on Substrate Moisture}

Four measured variables were selected: survey date (number of days after a rainfall), substrate composition, substrate depth and vegetation cover. However, vegetation cover, which did not significantly decrease the AIC $(<2)$, did not appear relevant for use in the Generalized Least Squares models (Table 2).

Table 2. Selection of variables used to choose the models. Model in bold is the one finally selected for this study. Resid.DF are the residual degrees of freedom and Resid.Dev is the residual deviance.

\begin{tabular}{|c|c|c|c|}
\hline Generalized Linear Model & AIC & Resid.Dev. & Resid.Df \\
\hline $\begin{array}{l}\text { moisture Survey_date*composition*depth- } \\
\text { date:composition:depth+vegetation cover }\end{array}$ & 3292.4 & 9824.1 & 565 \\
\hline moisture Survey_date*composition*depth-date:composition:depth & 3293.9 & 9882.8 & 566 \\
\hline moisture Survey_date*composition*depth+vegetation cover & 3293.2 & 9769.5 & 565 \\
\hline \multicolumn{4}{|l|}{ Generalized Least Squares } \\
\hline $\begin{array}{l}\log \left(\text { moisture+1) Survey_date }{ }^{*} \text { composition*depth- }\right. \\
\text { date:composition:depth }\end{array}$ & 1053.6 & 0.7220518 & 758 \\
\hline $\begin{array}{l}\log (\text { moisture+1) Survey_date*composition*depth- } \\
\text { date:composition:depth+vegetation cover }\end{array}$ & 1057.8 & 0.7231789 & 757 \\
\hline $\log \left(\right.$ moisture+1) Survey_date ${ }^{*}$ composition*depth+vegetation cover & 1067.5 & 0.7276123 & 755 \\
\hline
\end{tabular}

In the GLM, all the variables initially considered were significant at the 5\% alpha risk (Table 3) and no interaction between the variables was significant. The contribution of each parameter towards explaining some of the observed deviance in moisture levels was noted. The parameters contributing most to the explanation of model deviance were substrate composition and depth, and survey date. Vegetation cover contributed less to the explanation of deviance in moisture levels, but remained a significant variable in the model (Table 3). In fact, all these measured variables influenced substrate moisture, especially in November. 
Table 3. Deviance table (Generalized Linear Model (GLM) simple effects and Generalized Least Squares (GLS)) for the response status of soil moisture. Resid.DF are the residual degrees of freedom and Resid.dev is the residual deviance. Significance of the terms is given by the $p$-values (Signif. codes: $\left.<0.0001^{(* * * \prime} ;<0.001^{(* * \prime \prime} ;<0.05^{(* \prime}\right)$ of the chi-square test.

\begin{tabular}{|c|c|c|c|c|c|c|}
\hline Parameters & Df & Deviance & Resid. Df. & Resid. Dev & F-Value & $p$-Value \\
\hline \multicolumn{7}{|c|}{ Generalized Linear Model—Autumn data } \\
\hline NULL & & & 575 & $16,662.2$ & & \\
\hline Survey date & 1 & 2071.5 & 574 & $14,590.7$ & 119.13 & $<0.0001^{* * *}$ \\
\hline Composition & 2 & 4162.4 & 572 & $10,428.3$ & 119.70 & $<0.0001^{* * *}$ \\
\hline Depth & 1 & 360.5 & 571 & $10,067.8$ & 20.73 & $<0.0001^{* * *}$ \\
\hline Vegetation cover & 1 & 75.2 & 570 & 9992.6 & 4.32 & 0.038 * \\
\hline Survey date:Composition & 2 & 92.1 & 568 & 9900.4 & 2.65 & 0.07 \\
\hline Survey date:Depth & 1 & 9.5 & 567 & 9890.9 & 0.55 & 0.46 \\
\hline Composition:Depth & 2 & 83.3 & 566 & 9824.1 & 1.92 & 0.15 \\
\hline \multicolumn{7}{|c|}{ Generalized Least Squares-Summer data } \\
\hline (Intercept) & 1 & - & - & - & 1015.58 & $<0.0001^{* * *}$ \\
\hline Survey date & 1 & - & - & - & 215.99 & $<0.0001^{* * *}$ \\
\hline Composition & 2 & - & - & - & 43.43 & $<0.0001^{* * *}$ \\
\hline Depth & 1 & - & - & - & 633.83 & $<0.0001^{* * *}$ \\
\hline Survey date:Composition & 2 & - & - & - & 10.19 & $<0.0001^{* * *}$ \\
\hline Survey date:Depth & 1 & - & - & - & 7.13 & $0.0077 *$ \\
\hline Composition:Depth & 2 & - & - & - & 19.24 & $<0.0001^{* * *}$ \\
\hline
\end{tabular}

In the GLS model on the summer data, all the variables initially considered were significant at the $5 \%$ level, with the exception of vegetation cover (Table 3). Several possible first-degree interactions between the variables were significant at the $1 \%$ level. In these models, substrate composition and depth, and survey date, were always the most important explanatory variables. These three variables interacted significantly with each other: the interactions between composition and depth, as well as between substrate depth and survey date, appeared to be particularly significant in this model (Table 3).

Overall, the interpretation of the parameters was similar using the two modeling approaches for the two survey periods, as the parameters were constantly positive when the models were compared. The only major difference in these models was the effect of the interactions of variables for the summer period and the slight effect of vegetation cover for the autumn period, which was not significant for summer.

\subsection{Effect of Substrate Depth on Substrate Moisture}

Using significant interactions, the interpretation must take into account the effects of the main variable and the variable interacting at the same time. As for the interaction between substrate depth and survey date, obviously substrate moisture for all depth classes decreased over time and consequently decreased significantly after the last precipitation (Table 3). However, there was a significant effect of depth on substrate moisture (Figure 4A, Table 3). In summer, the 5-cm thick substrates had significantly higher moisture one day after rain than the $15-\mathrm{cm}$ substrates. After three days this result was reversed: the 5-cm substrates dried up much faster than the $15-\mathrm{cm}$ substrates, which kept their moisture content longer. The moisture level of the $15-\mathrm{cm}$ substrates tended to be stable five days after rain and higher than that of the $5-\mathrm{cm}$ substrates, where moisture was close to $0 \%$ (Figure 4A). Regardless of substrate composition, the 15-cm substrates tended to have higher moisture content than the 5 -cm substrates (Figure $4 \mathrm{~B}$ ).

In autumn, we observed significant differences between the two substrate depths $\left(\mathrm{F}_{1}=20.65\right.$, $p$-value $\left.<0.0001^{* * *}\right)$. The 5 -cm substrates were wetter in the first 10 days after rain than the $15-\mathrm{cm}$ substrates. Between two rainfalls, the relatively high substrate moisture decreased very little compared to the summer period. The substrates did not have time to completely dry out before the second rainfall, maintaining between $25 \%$ and $30 \%$ moisture content (Figure $4 \mathrm{~A}$ ). 


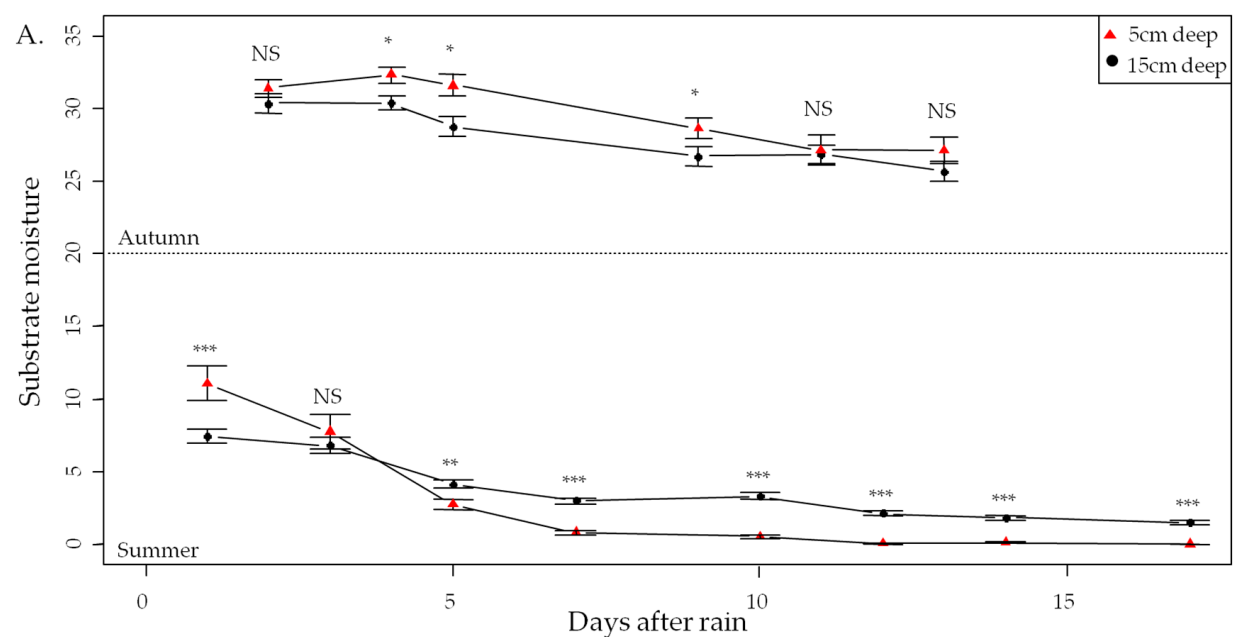

B.

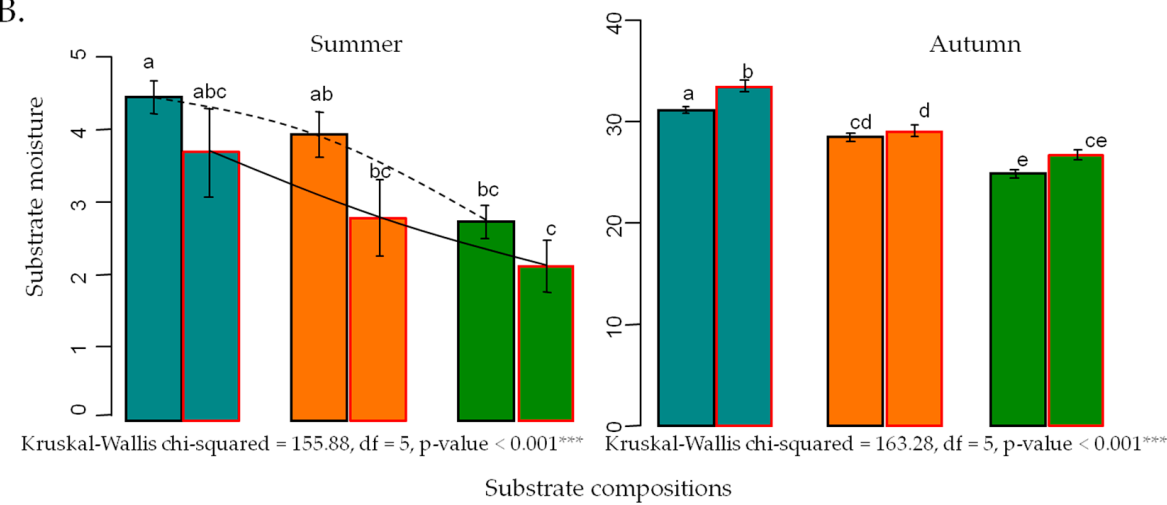

Figure 4. Interaction plot for soil moisture (from GLS and GLM) between (A) substrate depth and number of days after rain in summer and autumn 2016 (means and standard errors) and (B) Substrate composition with substrate depth, on the roof of Avignon IUT (Southeastern France) in summer and autumn 2016. Mixtures are indicated by the color background (blue: $25 \%$ pebble-sand and $75 \%$ clay-silt; orange: $50 \%$ pebble-sand and $50 \%$ clay-silt; green: $75 \%$ pebble-sand and $25 \%$ clay-silt) and the substrate thicknesses by the color of the quadrats framing (red: $5 \mathrm{~cm}$, black: $15 \mathrm{~cm}$ ). Values are means of substrate moisture \pm standard errors for each substrate thickness and for each survey period. The stars represent significant differences between the two thicknesses for a survey date, NS: not significant from the post hoc test of Mann-Whitney-Wilcoxon test. Two values in the same row with a different letter are significantly different according to Mann-Whitney-Wilcoxon test [52].

\subsection{Effet of Substrate Composition on Substrate Moisture}

The finer the particles (clays and silts), the higher the substrate moisture was. While this measure was true for autumn, with significant differences between all substrates $\left(F_{2}=119.70\right.$, $p$-value $<0.0001^{* * *}$ ) (Figure 5, Table 3), it was only a not significant trend in summer (Figure 5). 


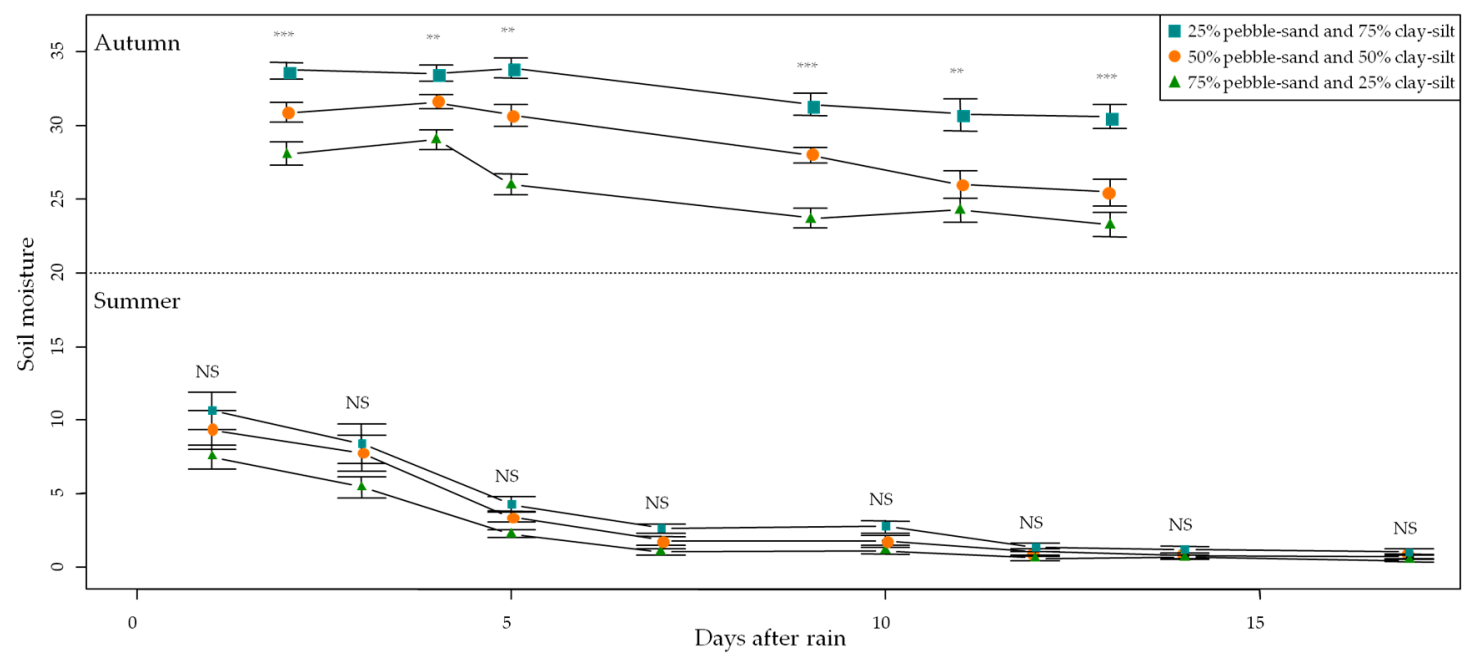

Figure 5. Evolution of substrate moisture according to substrate composition on the roof of Avignon IUT (Southeastern France) in summer and autumn 2016. Values are means of substrate moisture \pm standard errors for each substrate composition and for each survey period. The stars represent significant differences between the three substrate compositions for a survey date, NS: not significant from the post hoc test of Tukey HSD (Honest Significant Difference).

\subsection{Effet of Vegetation Cover on Substrate Moisture}

Despite the lack of significant correlation between vegetation cover and substrate moisture, a not significant trend was observed (Table 3): the higher the vegetation cover, the higher the substrate moisture. Moreover, the GLM showed that whatever the explanatory variable studied, vegetation cover was lower in summer: the experiment initiated in April 2016, when vegetation was just beginning to develop (Table 4). Season $\times$ substrate depth interaction highlighted a significant difference in vegetation cover, which was significantly greater in the $15-\mathrm{cm}$ substrates than in the $5-\mathrm{cm}$ substrates (Figure 6). In autumn, the finer-grained the substrate, the greater the vegetation cover was, whereas no significant difference was measured in summer (Figure 6).
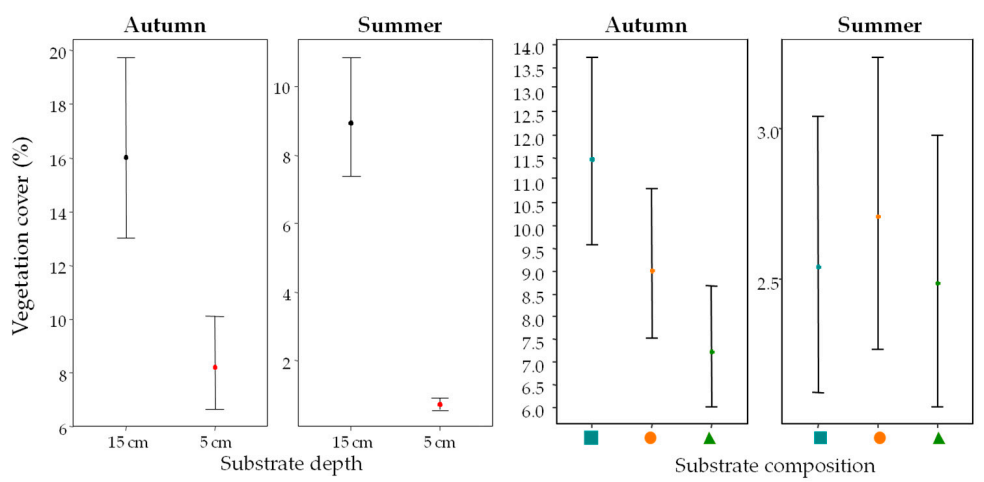

P5 $5 \mathrm{~cm}$ deep substrate $\mathbb{P 1 5} 15 \mathrm{~cm}$ deep substrate

$25 \%$ pebble-sand \& $75 \%$ clay-silt $50 \%$ pebble-sand \& $50 \%$ clay-silt $\mathbf{\Delta} 75 \%$ pebble-sand \& $25 \%$ clay-silt

Figure 6. Effect of season, substrate composition and substrate depth interactions on vegetation cover on the roof of Avignon IUT (Southeastern France) in summer and autumn 2016. Values are means \pm standard errors. 
Table 4. Deviance table for the negative binomial model for the response status of vegetation cover. Resid.DF are the residual degrees of freedom and Resid.dev is the residual deviance. Significance of the terms is given by the $p$-values (Signif. codes: $<0.0001^{(* * * \prime} ;<0.001^{(* * \prime} ;<0.05^{* *^{\prime}}$ ) of the chi-square test.

\begin{tabular}{cccccc}
\hline Parameters & Df & Deviance & Resid. Df. & Resid. Dev & $p$-Value \\
\hline & Generalized Linear Model, negative binomial model & \\
\hline NULL & & & 1343 & 2185.2 & \\
Depth & 1 & 258.713 & 1342 & 1926.5 & $<0.0001^{* * *}$ \\
Composition & 2 & 10.986 & 1340 & 1915.5 & $<0.01^{*}$ \\
$\quad$ Season & 1 & 235.183 & 1339 & 1680.3 & $<0.0001^{* * *}$ \\
$\begin{array}{c}\text { Composition: } \\
\quad \text { Season }\end{array}$ & 2 & 23.413 & 1337 & 1656.9 & $<0.0001^{* * *}$ \\
$\begin{array}{c}\text { Composition: } \\
\text { Depth }\end{array}$ & 2 & 40.081 & 1335 & 1616.8 & $<0.0001^{* * *}$ \\
$\quad$ Season: & 1 & 153.233 & 1334 & 1463.6 & $<0.0001^{* * *}$ \\
Depth & & & & & \\
\hline
\end{tabular}

\section{Discussion}

Substrate moisture behavior during dry periods is influenced by both substrate characteristics and climatic conditions [12,41,71,72]: substrate moisture depends not only on the type of rainfall event (intensity, duration), but on the way the substrate retains water. Of all the variables tested in this study, substrate depth has the strongest effect on substrate moisture, as expected from results classically obtained in in situ natural or cultivated soils. Increasing substrate depth also protects plants from extreme summer temperatures by increasing the potential reservoir of water available to plants, thereby reducing the risk of stress due to drought $[18,24,73]$. Substrates are also known to be subject to loss of all surface moisture [74], and this is accentuated during the summer season when thin substrates totally dry out. In addition, the surface layer of the substrate tends to compact rapidly. Thus, 5-cm substrates have very low structural porosity [36]. Structural porosity plays an important role in substrate-plant interactions, because it ensures water and air transfers and the storage of water usable by plants. The water retained within the clayey micro-aggregates, therefore, would not satisfy the water needs of the plants, which cannot exert sufficient suction to extract water from pores of less than a few tens of nanometers between clay particles [75]. This means that the water retained in the 5-cm substrates cannot be characterized as useful for the plants. In our case, we have measured that thin substrates have significantly higher moisture just after rain that can also lead to substrate compaction. A substrate thickness of $15 \mathrm{~cm}$ would therefore be more favorable to vegetation maintenance, as demonstrated in our results, especially in the summer period, when a reserve of water can be accumulated over a longer period. However, it should be borne in mind that increasing substrate depth has an economic cost (greater volume of substrate required) and may also not be feasible due to insufficient roof strength to support the substrate weight of nearly $250 \mathrm{~kg}$ per square meter in our case [19]. Substrate thickness therefore needs to be appropriate to the buildings and the ecological objectives involved. A useful addition might be bryophyte implantation, as they can help maintain a constant substrate moisture content, especially during summer [76,77]. This could facilitate the implantation of plant species adapted to water stress but requiring minimum soil moisture for their development, the ideal choice for Mediterranean extensive green roofs.

Apart from substrate moisture, another cause of compaction may be substrate particle size. This is borne out by the tendency of the substrates with a higher proportion of fine elements to have higher moisture than the other substrates, due to their lower draining power. Substrates with high proportions of fine elements are liable to compact at the surface under the effect of rain [36]. Crosaz [78] showed that rooting occurs faster in substrates where the particle size is finer. Because of the greater specific surface of many small mineral particles, their chemical alteration is more rapid and the transfer of mineral nutrients to the roots more abundant, making such a substrate more beneficial to plant 
development. This is confirmed by examining the relationship between vegetation cover and substrate composition in this study: when the substrate is composed of finer elements, vegetation cover is higher. However, substrates should not be composed of fine elements alone because they tend to retain water, preventing it from penetrating deeply. This makes the substrate impermeable at the surface and asphyxiates the roots [36]. Conversely, substrates with coarse elements have lower vegetation cover. Coarse elements ( $>2 \mathrm{~mm}$ ) appear to block the development of vegetation by reducing the volume of soil available to plants, thereby limiting their access to the necessary resources. Thus, the choice of substrate components and their proportion in green roofs is very important [19]. The ideal substrate for green roofs should therefore be a compromise, containing both fine and, in smaller quantities, coarse elements. In this study, the composition that seems to best accommodate and maintain vegetation adapted to the Mediterranean context is that with $75 \%$ fine and $25 \%$ coarse elements.

In addition to substrate composition, increasing substrate depth generally improves the growth and survival of green roof plants by increasing the availability of water and nutrients, especially during periods of drought $[18,25,73,79]$. At the same time, high vegetation cover on green roofs helps improve water retention $[42,80,81]$. It is therefore important to develop substrates that favor high vegetation cover, not only for aesthetic reasons but also to combat Mediterranean wind erosion (by local winds such as Bora, Mistral, Sirocco) which can deprive the substrate of fine elements, rendering it sterile [82].

The parameters measured in this study on substrates using materials that mimic natural soil composition show that our substrates offer the same properties as the standard artificial substrates used almost exclusively internationally (deeper substrates promoted greater survival and growth of plant species and had greater resistance to drought, retention capacity, etc.) $[18,73,81]$. Despite the difference in weight of the materials (pozzolana of thickness $5 \mathrm{~cm}$ is $40 \mathrm{~kg} \cdot \mathrm{m}^{-2}$ versus $80 \mathrm{~kg} \cdot \mathrm{m}^{-2}$ for our substrates of the same thickness), there are substantial economic advantages to using these innovative substrates. The pozzolana generally used for green roofs is a natural rock, which is extracted and then has to be crushed and sieved to achieve the desired granulometry. By contrast, the coarse elements used in this study are simply sifted without crushing and the fine elements are quarry wastes from leaching during production and do not have to be mined. The use of such materials, destined to be discarded, would limit the treatment of precious rocky resources. Moreover, alluvial quarries are far more common than pozzolana quarries in the Mediterranean area [83], thus enabling transport costs and ecological consequences to be reduced.

\section{Conclusions}

In this study, main findings are (1) that the explanatory variables influencing the substrates moisture are mainly depth and composition of the substrates mixtures in relation to the elapsed time since the last precipitation, and (2) that vegetation cover influences moisture to a lesser extent but is itself influenced by composition and depth of the substrates. For an optimal colonization of the vegetation, a substrate thickness of $15 \mathrm{~cm}$ composed mainly of clays and silt (75\% clay-silt and $25 \%$ pebble-sand) would be recommended for the installation of green roofs with such substrates in a Mediterranean climate context. This recommendation will be confirmed by a more detailed study of the vegetation during a period of three to five years.

In conclusion, any green roof project needs to clearly identify the type of substrate that will foster good development of the target plant species. In the Mediterranean context, it is important to choose low-draining substrates that conserve maximum moisture for plant development. A slightly deeper substrate is desirable, with a high proportion of fine elements. It should be borne in mind that composition and assemblages of plant species change over time, suggesting that customized seed mixtures cannot usually create communities without high maintenance (irrigation, fertilization and weed control). Therefore, if the goal is to develop resilient plant communities on extensive green roofs, it is essential to consider auto-reseeding as a design factor.

Acknowledgments: We gratefully acknowledge invaluable contributions to these experiments from doctoral students, technicians, students, our families and researchers: Anne Aurière, Flavie Lescure, Julien Chenot, 
Hervé Ramone, Christel Vidaller, Sébastien Dailly, Bastien Tresse, Olivier Blight, Lenka Brousset and Armin Bischoff. This study was supported by funds from Société des Carrières de La Ménudelle, a subsidiary of Gagneraud Construction. We would like to personally thank Pierre Bourguet and Jean-Marc Arnal for the quality of the materials provided and for their collaboration and valuable help in putting the projects together. We also thank the IUT for authorizing the experiments on the roof of the establishment. We also thank Coraline Bel, Jean-Pierre Vandervaere and Cedric Legout for their advice on soil physics. We thank Marjorie Sweetko for the revision of the English. Finally, we thank Martin Hermy for his advice on protocol development and two anonymous reviewers for their useful comments on the first version of this paper.

Author Contributions: J.C., R.J., E.B. T.D. conceived and designed the experiments; J.C., C.M. performed the experiments, J.C., E.G. analyzed the data and wrote the paper; C.M., R.J., E.B. T.D. contributed to revising the manuscript.

Conflicts of Interest: The authors declare no conflict of interest.

\section{References}

1. Perring, M.P.; Manning, P.; Hobbs, R.J.; Lugo, A.E.; Ramalho, C.E.; Standish, R.J. Novel Urban Ecosystems and Ecosystem Services. In Novel Ecosystems; Hobbs, R.J., Higgs, E.S., Hall, C.M., Eds.; John Wiley \& Sons Ltd.: Hoboken, NJ, USA, 2013; pp. 310-325. ISBN 978-1-118-35418-6.

2. Dvorak, B.; Volder, A. Green roof vegetation for North American ecoregions: A literature review. Landsc. Urban Plan. 2010, 96, 197-213. [CrossRef]

3. Fioretti, R.; Palla, A.; Lanza, L.G.; Principi, P. Green roof energy and water related performance in the Mediterranean climate. Build. Environ. 2010, 45, 1890-1904. [CrossRef]

4. Groenewegen, P.P.; van den Berg, A.E.; de Vries, S.; Verheij, R.A. Vitamin G: Effects of green space on health, well-being, and social safety. BMC Public Health 2006, 6, 149. [CrossRef] [PubMed]

5. Oberndorfer, E.; Lundholm, J.; Bass, B.; Coffman, R.R.; Doshi, H.; Dunnett, N.; Gaffin, S.; Köhler, M.; Liu, K.K.Y.; Rowe, B. Green Roofs as Urban Ecosystems: Ecological Structures, Functions, and Services. BioScience 2007, 57, 823-833. [CrossRef]

6. White, E.V.; Gatersleben, B. Greenery on residential buildings: Does it affect preferences and perceptions of beauty? J. Environ. Psychol. 2011, 31, 89-98. [CrossRef]

7. Brenneisen, S. Space for urban wildlife: Designing green roofs as habitats in Switzerland. Urban Habitats 2006, 4, 27-36.

8. Madre, F.; Vergnes, A.; Machon, N.; Clergeau, P. A comparison of 3 types of green roof as habitats for arthropods. Ecol. Eng. 2013, 57, 109-117. [CrossRef]

9. Kowarik, I. Novel urban ecosystems, biodiversity, and conservation. Environ. Pollut. 2011, 159, $1974-1983$. [CrossRef] [PubMed]

10. Madre, F.; Vergnes, A.; Machon, N.; Clergeau, P. Green roofs as habitats for wild plant species in urban landscapes: First insights from a large-scale sampling. Landsc. Urban Plan. 2014, 122, 100-107. [CrossRef]

11. Cook-Patton, S.C.; Bauerle, T.L. Potential benefits of plant diversity on vegetated roofs: A literature review. J. Environ. Manag. 2012, 106, 85-92. [CrossRef] [PubMed]

12. Soulis, K.X.; Ntoulas, N.; Nektarios, P.A.; Kargas, G. Runoff reduction from extensive green roofs having different substrate depth and plant cover. Ecol. Eng. 2017, 102, 80-89. [CrossRef]

13. Brudermann, T.; Sangkakool, T. Green roofs in temperate climate cities in Europe-An analysis of key decision factors. Urban For. Urban Green. 2017, 21, 224-234. [CrossRef]

14. Farrell, C.; Ang, X.Q.; Rayner, J.P. Water-retention additives increase plant available water in green roof substrates. Ecol. Eng. 2013, 52, 112-118. [CrossRef]

15. Vanuytrecht, E.; Van Mechelen, C.; Van Meerbeek, K.; Willems, P.; Hermy, M.; Raes, D. Runoff and vegetation stress of green roofs under different climate change scenarios. Landsc. Urban Plan. 2014, 122, 68-77. [CrossRef]

16. Benvenuti, S.; Bacci, D. Initial agronomic performances of Mediterranean xerophytes in simulated dry green roofs. Urban Ecosyst. 2010, 13, 349-363. [CrossRef]

17. Rowe, D.B.; Getter, K.L.; Durhman, A.K. Effect of green roof media depth on Crassulacean plant succession over seven years. Landsc. Urban Plan. 2012, 104, 310-319. [CrossRef]

18. Thuring, C.E.; Berghage, R.D.; Beattie, D.J. Green Roof Plant Responses to Different Substrate Types and Depths under Various Drought Conditions. HortTechnology 2010, 20, 395-401. 
19. Young, T.; Cameron, D.D.; Sorrill, J.; Edwards, T.; Phoenix, G.K. Importance of different components of green roof substrate on plant growth and physiological performance. Urban For. Urban Green. 2014, 13, 507-516. [CrossRef]

20. Banting, D.; Doshi, H.; Li, J.; Missios, P. Report on the Environmental Benefits and Costs of Green Roof Technology for the City of Toronto; City of Toronto and Ontario Centres for Excellence-Earth and Environmental Technologies; Ryerson University: Toronto, ON, Canada, 2005; p. 88.

21. Water Scarcity in the Mediterranean: Perspectives under Global Change; Sabater, S.; Barceló, D.; Eds.; The Handbook of Environmental Chemistry; Springer: Heidelberg, Germany; New York, NY, USA, 2010; ISBN 978-3-642-03970-6.

22. Van Mechelen, C.; Dutoit, T.; Kattge, J.; Hermy, M. Plant trait analysis delivers an extensive list of potential green roof species for Mediterranean France. Ecol. Eng. 2014, 67, 48-59. [CrossRef]

23. Li, W.C.; Yeung, K.K.A. A comprehensive study of green roof performance from environmental perspective. Int. J. Sustain. Built Environ. 2014, 3, 127-134. [CrossRef]

24. Dunnett, N.; Kingsbury, N. Planting Green Roofs and Living Walls; Timber Press: Portland, OR, USA, 2004; ISBN 978-0-88192-640-8.

25. Getter, K.L.; Rowe, D.B. The Role of Extensive Green Roofs in Sustainable Development. HortScience 2006, 41, 1276-1285.

26. Pledge, E. Green Roofs: Ecological Design and Construction; Schiffer Publishing: Atglen, PA, USA, 2005; ISBN 978-0-7643-2189-4.

27. Snodgrass, E.C.; Snodgrass, L.L. Green Roof Plants: A Resource and Planting Guide; Timber Press: Portland, OR, USA, 2006; ISBN 978-0-88192-787-0.

28. Hill, J.; Drake, J.; Sleep, B. Comparisons of extensive green roof media in Southern Ontario. Ecol. Eng. 2016, 94, 418-426. [CrossRef]

29. Nagase, A.; Dunnett, N. The relationship between percentage of organic matter in substrate and plant growth in extensive green roofs. Landsc. Urban Plan. 2011, 103, 230-236. [CrossRef]

30. FLL e.V. Guidelines for the Planning Construction and Maintenance of Green Roofing-Green Roofing Guideline; FLL e.V.: Bonn, Germany, 2008.

31. Getter, K.L.; Bradley Rowe, D.; Cregg, B.M. Solar radiation intensity influences extensive green roof plant communities. Urban For. Urban Green. 2009, 8, 269-281. [CrossRef]

32. Catalano, C.; Marcenò, C.; Laudicina, V.A.; Guarino, R. Thirty years unmanaged green roofs: Ecological research and design implications. Landsc. Urban Plan. 2016, 149, 11-19. [CrossRef]

33. Catalano, C.; Guarino, R.; Brennseisen, S. A plant sociological approach for extensive green roofs in Mediterranean areas. In Proceedings of the 11th Annual CitiesAlive Green Roof and Wall Conference is Securing Urban Resiliency with Living Architecture, San Francisco, CA, USA, 23-26 October 2013.

34. Allison, G. The Influence of Species Diversity and Stress Intensity on Community Resistance and Resilience. Ecol. Monogr. 2004, 74, 117-134. [CrossRef]

35. Nagase, A.; Dunnett, N. Establishment of an annual meadow on extensive green roofs in the UK. Landsc. Urban Plan. 2013, 112, 50-62. [CrossRef]

36. Baize, D.; Jabiol, B. Guide Pour la Description Des Sols; Éd. Quae: Versailles, France, 2011; ISBN 978-2-7592-1034-3.

37. Nofal, S. Étude du Fonctionnement Hydrodynamique de la Nappe Alluviale d'Avignon: Impact de L'usage du sol sur les Mécanismes de Recharge. Ph.D. Thesis, Université d'Avignon, Avignon, France, 2014.

38. Riser, J. Les Espaces du vent; Quae: Versailles, France, 2010; ISBN 978-2-7592-1225-5.

39. Celle, H. Caractérisation des Précipitations sur le Pourtour de la Méditerranée Occidentale: Approche Isotopique et Chimique. Ph.D. Thesis, Université d'Avignon, Avignon, France, 2000.

40. Huneau, F. Fonctionnement Hydrogéologique et Archives Paléoclimatiques d'un Aquifère Profond Méditerranéen: Étude Géochimique et Isotopique du Bassin Miocène de Valréas (Sud-Est de la France). Ph.D. Thesis, Université d'Avignon, Avignon, France, 2000.

41. Berretta, C.; Poë, S.; Stovin, V. Moisture content behaviour in extensive green roofs during dry periods: The influence of vegetation and substrate characteristics. J. Hydrol. 2014, 511, 374-386. [CrossRef]

42. Graceson, A.; Monaghan, J.; Hall, N.; Hare, M. Plant growth responses to different growing media for green roofs. Ecol. Eng. 2014, 69, 196-200. [CrossRef]

43. Hermy, M.; Schauvliege, M.; Tijskens, G. Groenbeheer, een Verhaal met Toekomst; Velt: Berchem, Belgium, 2005; ISBN 978-90-806622-2-3. 
44. Thomas, G.W. Soil pH and Soil Acidity. In Methods of Soil Analysis Part 3-Chemical Methods; Sparks, D.L., Page, A.L., Helmke, P.A., Loeppert, R.H., Soltanpour, P.N., Tabatabai, M.A., Johnston, C.T., Sumner, M.E., Eds.; Soil Science Society of America Book Series; American Society of Agronomy: Madison, WI, USA, 1996; Volume 5, pp. 475-490.

45. Sparks, D.L.; Page, A.L.; Helmke, P.A.; Loeppert, R.H.; Soltanpour, P.; Tabatabai, M.A.; Johnston, C.T.; Sumner, M.E. Methods of Soil Analysis. Part 3-Chemical Methods; American Society of Agronomy: Madison, WI, USA, 1996; p. 1390.

46. Allison, L.E. Organic carbon. In Methods of Soil Analysis; Black, C.A., Evans, D.D., White, J.L., Enisminger, L.E., Clark, F.E., Eds.; American Society of Agronomy: Madison, WI, USA, 1965; pp. 1372-1378.

47. Bremner, J.M. Nitrogen-Total. In Methods of Soil Analysis. Part 3-Chemical Methods; Sparks, D.L., Page, A.L., Helmke, P.A., Loeppert, R.H., Soltanpour, P.N., Tabatabai, M.A., Johnston, C.T., Sumner, M.E., Eds.; Soil Science Society of America Book Series; American Society of Agronomy: Madison, WI, USA, 1996; Volume 5, pp. 1085-1121.

48. Dumas, J. Procédés de l'analyse organique. Ann. Chem. Phys. 1831, 47, 198-213.

49. Metson, A.J. Methods of Chemical Analysis for Soil Survey Samples; New Zealand Department of Scientific and Industrial Research: Wellington, New Zealand, 1956.

50. Ciesielski, H.; Sterckeman, T.; Santerne, M.; Willery, J.P. A comparison between three methods for the determination of cation exchange capacity and exchangeable cations in soils. Agron. Sustain. Dev. 1997, 17, 9-16. [CrossRef]

51. Olsen, S.R. Estimation of Available Phosphorus in Soils by Extraction with Sodium Bicarbonate; US Department of Agriculture: Washington, DC, USA, 1954.

52. Bonferroni, C.E. Teoria statistica delle classi e calcolo delle probabilità. Pubbl. R Ist. Super. Sci. Econ. E Commer. Firenze 1936, 8, 3-62.

53. Rieux, R.; Ritschel, G.; Roux, C. Etude écologique et phytosociologique du Crassuletum tillaeae Molinier et tallon 1949. Rev. Biol. Décologie Méditerranéenne 1977, 4, 117-143.

54. Coiffait-Gombault, C. Règles D'assemblages et Restauration Écologique des Communautés Végétales Herbacées Méditerranéennes: Le Cas de la Plaine de La Crau (Bouches-du-Rhône, France). Ph.D. Thesis, Université d'Avignon, Avignon, France, 2011.

55. Badan, O.; Congés, G.; Brun, J.-P. Les bergeries romaines de la Crau d'Arles. Les origines de la transhumance en Provence. Gallia 1995, 52, 263-310. [CrossRef]

56. Cherel, O. Contribution à L'étude des Relations Végétation-Mouton sur les Parcours de Crau (S.E. France): Adaptation et Développement de Méthodes d'Étude du Régime Alimentaire. Ph.D. Thesis, Université Aix Marseille 1, Marseille, France, 1988.

57. Henry, F. Origine et Dynamique à Long Terme d'un Écosystème Herbacé Pseudo Steppique, le Cas de la Plaine de La Crau (Bouches du Rhône, France). Ph.D. Thesis, Université Paul-Cézanne, Marseille, France, 2009.

58. Molinier, R.; Tallon, G. La Végétation de la Crau (Basse-Provence); Librairie générale De L'enseignement: Paris, France, 1950.

59. Gomila, H. Relation Sol-Végétation Dans la Plaine de Crau (sud-est de la France); Aix-Marseille III University: Marseille, France, 1987.

60. Buisson, E.; Jaunatre, R.; Römermann, C.; Bulot, A.; Dutoit, T. Seed bank studies in Mediterranean grassland: Lessons learnt from restoration projects. Restor. Ecol. 2017, in preparation.

61. AT Delta-T Devices Ltd. ML3 ThetaProbe. Soil Moisture an Temperature Sensor. Quick Start Guide, version 1.0; AT Delta-T Devices Ltd.: Cambridge, UK, 2013.

62. Thornthwaite, C.W. An Approach toward a Rational Classification of Climate. Geogr. Rev. 1948, 38, 55-94. [CrossRef]

63. Coelho, R.; Infante, P.; Santos, M.N. Application of Generalized Linear Models and Generalized Estimation Equations to model at-haulback mortality of blue sharks captured in a pelagic longline fishery in the Atlantic Ocean. Fish. Res. 2013, 145, 66-75. [CrossRef]

64. McCullagh, P. Generalized linear models. Eur. J. Oper. Res. 1984, 16, 285-292. [CrossRef]

65. Yardin, C. Estimer la droite d'étalonnage avec les moindres carrés généralisés et évaluer le résultat de mesure. Rev. Fr. Métrol. 2013, 21-39. [CrossRef] 
66. Zuur, A.F.; Ieno, E.N.; Walker, N.; Saveliev, A.A.; Smith, G.M. Mixed Effects Models and Extensions in Ecology with R; Statistics for Biology and Health; Springer: New York, NY, USA, 2009; ISBN 978-0-387-87457-9.

67. Burnham, K.P.; Anderson, D.R. Multimodel Inference: Understanding AIC and BIC in Model Selection. Sociol. Methods Res. 2004, 33, 261-304. [CrossRef]

68. R Development Core Team. R: A Language and Environment for Statistical Computing. Reference Index; R Foundation for Statistical Computing: Vienna, Austria, 2016; p. 3501.

69. Pinheiro, J.; Bates, D.; DebRoy, S.; Sarkar, D. Package "nlme": Linear and Nonlinear Mixed Effects Models; R Package Version 31-131; 2017; p. 336. Available online: https://cran.r-project.org/web/packages/nlme/ index.html (accessed on 25 October 2017).

70. Bates, D.; Maechler, M.; Bolker, B.; Walker, S.; Christensen, R.H.B.; Singmann, H.; Dai, B.; Grothendieck, G.; Green, P. Package "Ime4": Linear Mixed-Effects Models Using 'Eigen' and S4; R Package Version 11-12; 2016; p. 113. Available online: http:/ / keziamanlove.com/wp-content/uploads/2015/04/StatsInRTutorial.pdf (accessed on 25 October 2017).

71. Palla, A.; Gnecco, I.; Lanza, L.G. Hydrologic Restoration in the Urban Environment Using Green Roofs. Water 2010, 2, 140-154. [CrossRef]

72. Poë, S.; Stovin, V.; Berretta, C. Parameters influencing the regeneration of a green roof's retention capacity via evapotranspiration. J. Hydrol. 2015, 523, 356-367. [CrossRef]

73. Durhman, A.K.; Rowe, D.B.; Rugh, C.L. Effect of Substrate Depth on Initial Growth, Coverage, and Survival of 25 Succulent Green Roof Plant Taxa. HortScience 2007, 42, 588-595.

74. Douguedroit, A. Le rôle de l'humidité des sols dans l'opposition de la végétation entre adrets et ubacs. Bull. Assoc. Géogr. Fr. 1974, 51, 133-140. [CrossRef]

75. Tisdall, J.M.; Oades, J.M. Organic matter and water-stable aggregates in soils. J. Soil Sci. 1982, 33, 141-163. [CrossRef]

76. Hettenbergerová, E.; Hájek, M.; Zelený, D.; Jiroušková, J.; Mikulášková, E. Changes in species richness and species composition of vascular plants and bryophytes along a moisture gradient. Preslia Čas. Čes. Bot. Spol. 2013, 85, 369-388.

77. Smith, A.J.E. Bryophyte Ecology; Springer Science \& Business Media: New York, NY, USA; Chapman and Hall: London, UK; New York, NY, USA, 1982; ISBN 978-94-009-5891-3.

78. Crosaz, Y. Lutte Contre L'érosion des Terres Noires en Montagne Méditerranéenne. Connaissance du Matériel Végétal Herbacé et Quantification de son Impact sur L'érosion. Ph.D. Thesis, Université de Droit, D'économie et des Sciences-Aix-Marseille III, Marseille, France, 1995.

79. Getter, K.L.; Rowe, D.B. Media depth influences Sedum green roof establishment. Urban Ecosyst. 2008, 11, 361. [CrossRef]

80. Berghage, R.D.; Jarrett, A.; Beattie, D.J.; Kelley, K.; Husain, S.; Rezai, F.; Long, B.; Negassi, A.; Cameron, R.; Hunt, W. Quantifying Vvaporation and Transpirational Water Losses from Green Roofs and Green Roof Media Capacity for Neutralizing Acid Rain; The Pennsylvania State University: State College, PA, USA, 2007; p. 94.

81. Stovin, V.; Poë, S.; De-Ville, S.; Berretta, C. The influence of substrate and vegetation configuration on green roof hydrological performance. Ecol. Eng. 2015, 85, 159-172. [CrossRef]

82. Faurie, C. Ecologie: Approche Scientifique et Pratique; Lavoisier: Paris, France, 2011; ISBN 978-2-7430-1310-3.

83. UNICEM. Statistiques 2015. Union Nationale des Industries de Carrières et Matériaux de Construction; UNICEM: Paris, France, 2017.

(C) 2017 by the authors. Licensee MDPI, Basel, Switzerland. This article is an open access article distributed under the terms and conditions of the Creative Commons Attribution (CC BY) license (http://creativecommons.org/licenses/by/4.0/). 